\title{
Splenic marginal zone lymphoma: A case report and review of the literature
}

\author{
Prachi $^{1}$, Hema Malini Aiyer ${ }^{2}$ \\ From ${ }^{1}$ Senior Resident, ${ }^{2} \mathrm{Head}$, Department of Pathology, Dharamshila Narayana Superspeciality Hospital, New Delhi
}

\begin{abstract}
Splenic marginal zone lymphoma (SMZL) is a low-grade B-cell non-Hodgkin's lymphoma characterized by massive splenomegaly, moderate lymphocytosis with or without villous lymphocytes, rare involvement of peripheral lymph nodes, and indolent clinical course. SMZL has a distinct immunologic profile which when correlated with the morphologic findings of peripheral blood and bone marrow aspirates as well as clinical and hematologic features enables accurate diagnosis and obviates the need for further invasive diagnostic procedures. Here, we present a case of SMZL who presented with massive splenomegaly and was diagnosed on the basis of clinical, hematological, and characteristic immunophenotypic findings on bone marrow aspirate and biopsy.
\end{abstract}

Key words: Aspirate, Biopsy, Immunophenotyping, Splenic marginal zone lymphoma

$\mathrm{S}$ plenic marginal zone (MZ) lymphoma (SMZL) comprises less than $2 \%$ of all lymphoid neoplasms [1,2]. Indolent B-cell lymphomas that derive from the $\mathrm{MZ}$ encompass three distinct entities: Extranodal MZ lymphoma of mucosa-associated lymphoid tissue (lymphoma), nodal MZL, and SMZL. SMZL is a B-cell neoplasm composed of small round lymphocytes that surround and replace the splenic white pulp germinal centers, efface the follicle mantle, and merge with a peripheral (marginal) zone of larger cells with pale cytoplasm, including scattered transformed blasts. Both small and larger cells infiltrate the red pulp.

The median age at diagnosis of SMZL is 69 years. The overall age-adjusted incidence is $0.13 / 100,000$ per year [1,3]. SMZL is the second most common subtype of MZ lymphoma, comprising about $20 \%$ of the cases. It represents about $0.9 \%$ of all non-Hodgkin's lymphoma and was recognized as a specific pathological entity only in 1991 [2]. The 2016 World Health Organization classification has maintained the distinction between the three diseases according to the organ where it arises and introduced a new provisional category of splenic B-cell lymphoma/leukemia, unclassifiable encompassing, splenic diffuse red pulp small B-cell lymphoma (SDRPL), and hairy cell leukemia variant (HCL-V) [2]. Primary splenic small B-cell lymphomas mostly comprise the distinct entity of SMZL and the provisional category of splenic lymphoma/leukemia unclassifiable, mainly represented by the HCL-V and SDRPL.

We demonstrated that a detailed immunohistopathologic bone marrow biopsy (BMB) evaluation offers adequate evidence for the confirmation of these entities and their differential diagnosis from

\section{Access this article online}

Received - 17 September 2020

Initial Review - 03 October 2020

Accepted - 07 October 2020

DOI: $10.32677 /$ IJCR.2020.v06.i10.010 other small B-cell lymphoma histotypes. A paired assessment of BMB and aspirate along with flow cytometry was conducted. While intrasinusoidal infiltration of the bone marrow is the rule in SDRL with or without interstitial and nodular infiltrates, the presence of lymphoid follicles with the germinal center is a feature of SMZL and has not been reported in SDRL.

\section{CASE REPORT}

We present the case of a 57-year-old female, with complaints of generalized weakness, loss of appetite, poor oral intake, pain abdomen, and nausea with two episodes of hematemesis in the past 15 days and melena for 10 days. Her upper gastrointestinal endoscopy and biopsy done elsewhere 3 years back were reported as a diffuse large B-cell lymphoma (GCB) type. The patient subsequently received five cycles of R-CHOP (rituximab, cyclophosphamide, vincristine, and doxorubicin). Her Eastern Oncology Group Performance was 90\%.

The patient presented to the department of hemato-oncology in our hospital with massive splenomegaly. She had a lowgrade fever, blood pressure of 108/59 mmHg, pulse rate of 97 beats per min, respiratory rate of 14 breaths per minute, and oxygen saturation was $97 \%$. There was no scleral icterus. On local examination, the abdomen was soft, with tenderness in the epigastrium, the spleen was firm and non-tender and extended to the left lower quadrant and the supraumbilical region. The remainder of the examination was normal.

Hemogram and blood counts showed absolute lymphocytosis with hemoglobin $7 \mathrm{~g} / \mathrm{dl}$, total leukocyte count of $17,200 / \mathrm{mm}^{3}$ (polymorphs $-16 \%$, lymphocytes $-82 \%$, and eosinophils $-2 \%$ ),

Correspondence to: Dr. Hema Malini Aiyer, Department of Pathology, Dharamshila Narayana Superspeciality Hospital, New Delhi, India. E-mail: hema.maliniaiyer.dr@narayanahealth.org

(C) 2020 Creative Commons Attribution-NonCommercial 4.0 International License (CC BY-NC-ND 4.0). 
and platelet count of $150,000 / \mathrm{mm}^{3}$. The patient underwent a bone marrow trephine biopsy and aspiration and a single linear bony tissue core measuring $1.2 \mathrm{~cm}$ was received. The histopathological stained sections showed a hypercellular marrow for age with $70-80 \%$ cellularity and trilineage hematopoiesis. Focal nonparatrabecular interstitial nodular aggregates of atypical smallto-medium lymphoid cells were seen with irregular nuclei, inconspicuous nucleoli, and focal residual germinal centers (Fig. 1a and b). Immunohistochemistry (IHC) was performed and expressed CD20 (Fig. 1c) and was negative for CD5, CD10, cyclin D1/BCL1, CD23, annexin A1, CD25, CD103, and CD123 (Figs. 1d and 2) (Table 1). Flow cytometry performed on the aspirate revealed $18-20 \%$ of B cells which were positive for CD19 and CD 79b and negative for CD5, CD10, CD103, and CD23.

Based on the clinical, hematological, bone marrow aspirate/ biopsy, and IHC/flow cytometry findings, a diagnosis of SMZL was rendered. The patient was on treatment with antibody therapy of rituximab and was followed up by maintenance therapy. The treatment course was uneventful.

\section{DISCUSSION}

MZLs represent a group of lymphoid tumors that originate from memory B-lymphocytes normally present in a distinct microanatomic compartment, the so-called MZ of the secondary lymphoid follicles.

SMZL is a B-cell neoplasm composed of small lymphocytes that surround and replace the white pulp follicles and merge with a peripheral zone of larger MZ-like cells, including scattered transformed blasts, thus giving rise to the characteristic biphasic pattern. It accounts for $<2 \%$ of all non-Hodgkin lymphoma and only $8.3 \%$ of all lymphoproliferative disorders involving the spleen [4]. Molecular dysregulation of NF-kB, NOTCH2, and KLF2 genes is associated with SMZL lymphomagenesis. These mutated genes are associated with $35 \%, 40 \%$, and $20-40 \%$ of cases of SMZL, respectively [4].

Diagnosing SMZL and distinguishing it from similar indolent B-cell lymphoproliferative disorders can be challenging. Until recently, the histopathological examination of splenectomy specimens was considered mandatory for the diagnosis of SMZL. However, currently due to advances in chemoimmunotherapy, splenectomy is performed infrequently. Therefore, bone marrow histopathology may be the sole determinant in the diagnosis of SMZL and SDRL.

The median overall survival in SMZL ranges between 5 and 10 years, but in cases of aggressive disease, seen in approximately one-third of patients, median survival is $<4$ years [5]. The differential diagnosis includes other small B-cell lymphomas/ leukemia such as chronic lymphocytic leukemia, HCL, mantle cell lymphoma, follicular lymphoma, and lymphoplasmacytic lymphoma (Table 2). SMZL infiltration into bone marrow has been reported in $67-100 \%$ of the cases at the time of diagnosis [6].

Asymptomatic patients do not require any treatment. Therapy is indicated only in symptomatic patients. Nowadays, splenectomy is usually not done and rituximab monotherapy is used as first-line therapy in the treatment of SMZL. In patients with disseminated disease, rituximab along with chemotherapy (cyclophosphamide, vincristine, doxorubicin, and prednisone) is indicated [7].

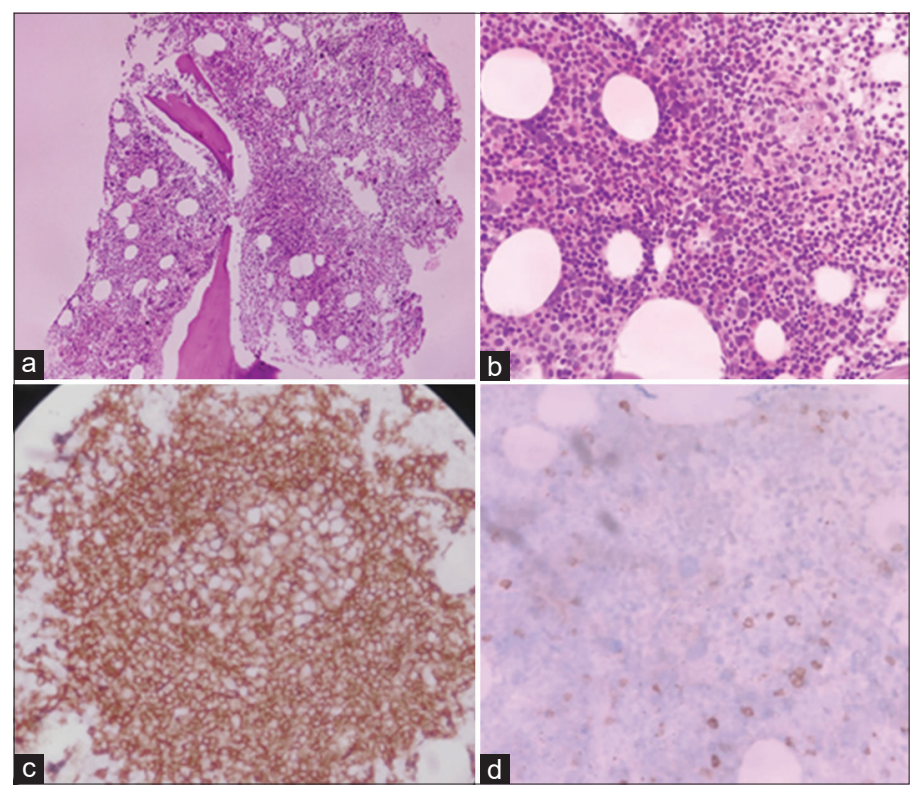

Figure 1: Non-paratrabecular interstitial nodular aggregate of atypical lymphoid cells (hematoxylin and eosin, $\times 100$ ); (b) Smallto-medium lymphoid cells were seen with irregular nuclei and inconspicuous nucleoli and focal residual germinal centers (hematoxylin and eosin, x400); (c) Immunoreactive score 4+ in neoplastic cells of lymphoid aggregates and in sinusoids of marrow (IHC stain, CD20; $\times 400$ ); (d) Non-immunoreactive score " 0 " in neoplastic (IHC stain, CD5; ×400)

Table 1: Immunohistochemistry markers done on bone marrow biopsy

\begin{tabular}{|c|c|c|}
\hline Antibody & [Clone] & Interpretation \\
\hline CD5 & [EP-7] & $\begin{array}{l}\text { Non-immunoreactive score " } 0 \text { " in } \\
\text { neoplastic cells }\end{array}$ \\
\hline CD10 & [56C6] & $\begin{array}{l}\text { Non-immunoreactive score " } 0 \text { " in } \\
\text { neoplastic cells }\end{array}$ \\
\hline $\mathrm{CD} 20$ & [L-26] & $\begin{array}{l}\text { Immunoreactive score } 4+\text { in neoplastic } \\
\text { cells of lymphoid aggregates and in } \\
\text { sinusoids of marrow }\end{array}$ \\
\hline $\mathrm{CD} 23$ & [EP-75] & $\begin{array}{l}\text { Non-immunoreactive score " } 0 \text { " in } \\
\text { neoplastic cells (immunoreactive in } \\
\text { follicular dendritic cells) }\end{array}$ \\
\hline CD25 & [RB4] & $\begin{array}{l}\text { Non-immunoreactive score " } 0 \text { " in } \\
\text { neoplastic cells }\end{array}$ \\
\hline CD43 & [DF41] & $\begin{array}{l}\text { Non-immunoreactive score " } 0 \text { " in } \\
\text { neoplastic cells (immunoreactive in } \\
\text { myeloid cells) }\end{array}$ \\
\hline CD103 & [EP206] & $\begin{array}{l}\text { Non-immunoreactive score " } 0 \text { " in } \\
\text { neoplastic cells }\end{array}$ \\
\hline CD123 & [BSB59] & $\begin{array}{l}\text { Non-immunoreactive score " } 0 \text { " in } \\
\text { neoplastic cells }\end{array}$ \\
\hline Annexin A1 & [BSB-95] & $\begin{array}{l}\text { Non-immunoreactive score " } 0 \text { " in } \\
\text { neoplastic cells (immunoreactive in } \\
\text { myeloid cells) }\end{array}$ \\
\hline Cyclin D1 & [SP4-R] & $\begin{array}{l}\text { Non-immunoreactive score " } 0 \text { " in } \\
\text { neoplastic cells }\end{array}$ \\
\hline
\end{tabular}


Table 2: Immunophenotypic analysis of SMZL and other B-cell lymphoproliferative disorders

\begin{tabular}{|c|c|c|c|c|c|c|c|}
\hline $\begin{array}{l}\text { B- cell lymphoproliferative } \\
\text { disorders }\end{array}$ & CD5 & CD19 & CD20 & CD23 & CD79b & CD10 & CD103 \\
\hline Our case (SMZL) & - & + & + & - & + & - & - \\
\hline HCL & - & + & + & - & + & - & + \\
\hline $\mathrm{HCL}-\mathrm{v}$ & - & + & + & - & + & - & $-/+$ \\
\hline SDRPL & $-1+$ & + & + & - & + & - & - \\
\hline CLL/SLL & + & + & $-/+$ & + & + & - & - \\
\hline FL & - & + & + & $-1+$ & + & + & - \\
\hline MCL & + & + & $-1+$ & $-1+$ & + & - & - \\
\hline LPL & - & + & + & - & + & - & - \\
\hline
\end{tabular}

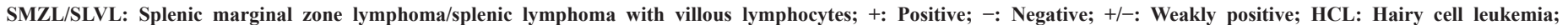

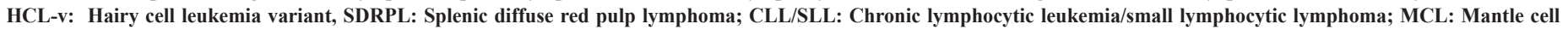
lymphoma; FL: Follicular lymphoma; LPL: Lymphoplasmacytic lymphoma

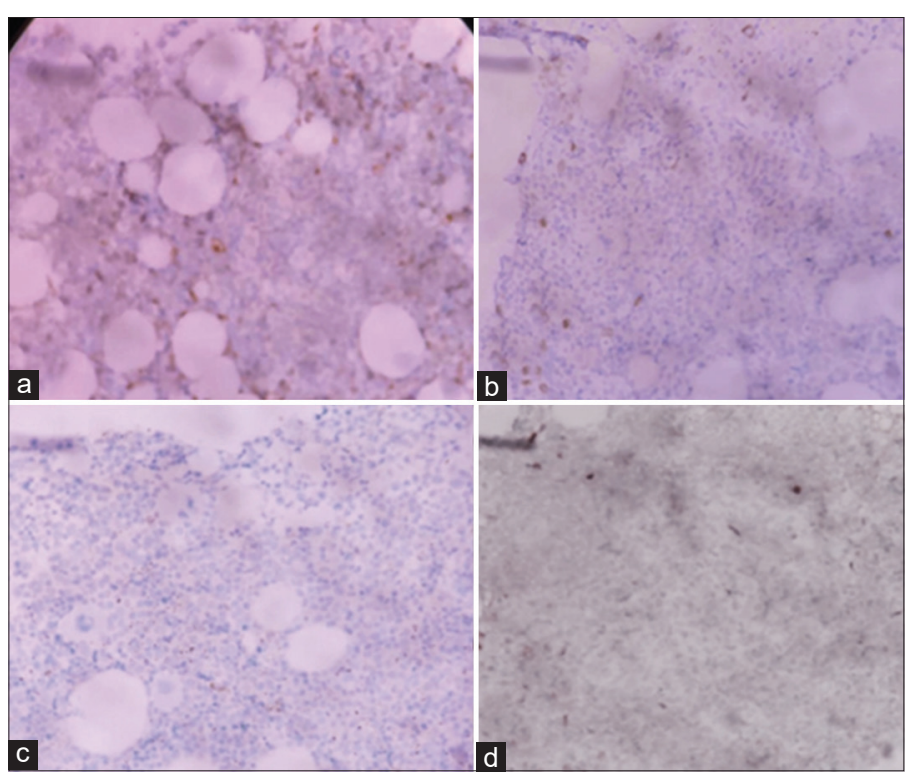

Figure 2: (a) Non-immunoreactive score " 0 " in neoplastic cells (immunoreactive in myeloid cells) (IHC stain, annexin a1; ×400). (b) Non-immunoreactive score " 0 " in neoplastic cells (immunoreactive in myeloid cells) (IHC stain, cyclin d1; $\times 400)$. (c) Non-immunoreactive score " 0 " in neoplastic cells (immunoreactive in follicular dendritic cells) (IHC stain, CD23; $\times 400)$. (d) Non-immunoreactive score " 0 " in neoplastic cells (IHC stain, CD103; $\times 400$ )

An international study of 593 SMZL patients identified hemoglobin, platelet count, high lactate dehydrogenase level, and extrahilar lymphadenopathy as parameters independently associated with lymphoma-specific survival (LSS). Three risk groups were identified with a significantly different 5 -year LSS of $94 \%, 78 \%$, and $69 \%$, respectively. These scores have been validated in an independent series of SMZL patients [8].

\section{CONCLUSION}

The pjresent case illustrates that it is possible to diagnose SMZL on bone marrow biopsies/aspirates and to emphasize that a correlation of immunophenotypic findings with clinical and hematologic features of patients coupled with careful and detailed morphological examination can lead to the correct diagnosis. The presence of classical cell morphology along with flow cytometric immunophenotyping and typical nodular, interstitial, and intrasinusoidal pattern of infiltration by CD20positive cells in the bone marrow is important clues to the diagnosis of SMZL which is pivotal in the management of the patient as this will guide the hemato-oncologist to a precise therapeutic intervention.

\section{REFERENCES}

1. Matutes E, Oscier D, Montalban C, Berger F, Callet-Bauchu E, Dogan A, et al. Splenic marginal zone lymphoma proposals for a revision of diagnostic, staging and therapeutic criteria. Leukemia 2008;22:487-95.

2. Campo E, Swerdlow SH, Harris NL, Pileri S, Stein H, Jaffe ES. The 2008 WHO classification of lymphoid neoplasms and beyond: Evolving concepts and practical applications. Blood 2011;117:5019-32.

3. Zinzani PL. The many faces of marginal zone lymphoma. Hematology Am Soc Hematol Educ Program 2012;2012:426-32.

4. Brox A, Bishinsky JI, Berry G. Primary non-Hodgkin lymphoma of the spleen. Am J Hematol 1991;38:95-100.

5. Bertoni F, Zucca E. State-of-the-art therapeutics: Marginal-zone lymphoma. J Clin Oncol 2005;23:6415-20.

6. Dierlamm J, Wlodarska I, Michaux L, Stefanova M, Hinz K, van den Berghe $\mathrm{H}$, et al. Genetic abnormalities in marginal zone B-cell lymphoma. Hematol Oncol 2000;18:1-13.

7. Arcaini L, Rossi D, Paulli M. Splenic marginal zone lymphoma: From Genetics to management. Blood 2016;127:2072-81.

8. Montalbán C, Abraira V, Arcaini L, Domingo E, Guisado P, Lannitto E, et al. Risk stratification for splenic marginal zone lymphoma based on haemoglobin concentration, platelet count, high lactate dehydrogenase level and extrahilar lymphadenopathy: Development and validation on 593 cases. Br J Haematol 2012;159:164-71.

Funding: None; Conflicts of Interest: None Stated.

How to cite this article: Prachi, Aiyer HM. Splenic marginal zone lymphoma: A case report and review of the literature. Indian J Case Reports. 2020;6(10):575-577. 